\title{
Concluding Remarks on the Symposium on the Evolutionary Advantage of Cost Accounting and Conservatism
}

\author{
${ }^{1}$ Institute of Management and Economics, Clausthal University of Technology, Clausthal-Zellerfeld, Cermany, E-mail: \\ eduard.braun@tu-clausthal.de. https://orcid.org/0000-0002-1752-4287.
}

Keywords: revenue-expense approach, balance-sheet approach, ecological rationality DOI: 10.1515/ael-2017-0049

On the Evolutionary Advantage of Cost Accounting and Conservatism

1 Braun, E. (2016). The Ecological Rationality of Historical Costs and Conservatism. doi: https://doi.org/10.1515/ael-2015-0013.

2 Basu, S. \& Waymire, G. (2017). Historical Cost and Conservatism Are Joint Adaptations That Help Identify Opportunity Cost. doi: https://doi.org/10.1515/ael-2016-0070.

3 Saito, S. \& Fukui, Y. (2016). Whither the Concept of Income? doi: https://doi.org/10.1515/ael-2016-0013.

4 Tang, V. (2017). The Role of Accounting and the Debate between Historical Cost and Fair Value. doi: https://doi.org/10.1515/ael-2016-0066.

5 Baker, C. (2016). Commentary on Braun's "The Ecological Rationality of Historical Costs and Conservatism" doi: https:/ /doi.org/10.1515/ael-2017-0049.

6 Braun, E. (2017). Concluding Remarks on the Symposium on the Evolutionary Advantage of Cost Accounting and Conservatism. doi: https://doi.org/10.1515/ael-2017-0049.

Although the other contributors generally agree with what I have written in my article, I think that the following statement by Basu and Waymire (2017) summarizes the relationship between my article and the subsequent essays and comments in the best way: "Braun (2017) ignores the contracting use of accounting principles because he abstracts away from all stewardship, accountability and contracting issues." I would like to explain briefly my perspective on this matter.

The reason why I became interested in questions of financial accounting as an outsider stemmed from my research on capital and entrepreneurship. I wanted to augment my knowledge about economic calculation with how it occurs in actual business life. While studying the relevant literature, I learned that there are basically two competing approaches to financial accounting. My impression was that their respective theoretical foundations differed strongly in character. The balance-sheet approach is based or at least is closely related to today's neoclassical economics. The adherents of the revenue-expense approach, on the other hand, do not systematically rely on a coherent theoretical system; the American institutionalism and the German historical school that could serve as a proper foundation (Biondi, 2013) live in the shadow nowadays. Here and there I found some short remarks on the relationship between Prospect Theory and the principles of historical costs and conservatism that sounded promising to me, yet had not been elaborated at greater length. That is the gap in the literature that I thought needed to be filled and that led me to write the article even though I was well aware of my status as a non-specialist.

Basu and Waymire are therefore correct in their statement quoted at the outset of this short rejoinder when they point out the limitations of my article. I welcome the important and necessary comments and criticisms, made by several renowned accounting theorists included in this volume. I would also like to use this opportunity to thank all contributors for applying so much effort to clarifying and shaping those issues that I covered only unsatisfactorily or not at all.

Whereas I made a general point about the relationship between neoclassical economics and the balancesheet approach, Baker (2017) adds his knowledge of the current state of the accounting regulations which are (as

Eduard Braun is the corresponding author.

(c) 2019 Walter de Gruyter $\mathrm{GmbH}$, Berlin/Boston.

This content is free. 
yet) far from following the balance-sheet approach completely. Baker also provides some historical perspective by referring to the discussion of the two approaches to financial accounting in the German Reich.

Tang (2017) adds the idea that the choice between the balance-sheet and the revenue-expense approaches depends on the function that accounting is to serve. If we need periodic information on either the value or performance of a firm in the capital markets, the balance-sheet approach will be, under certain conditions, the appropriate choice.

Basu and Waymire (2017), like Tang, point out where and how far fair-value accounting could be the better choice in certain situations. Furthermore, Basu and Waymire push the arguments that I assembled and elaborated in my article further by introducing firm-specific issues like internal quasi-prices.

Saito and Fukui (2017) provide of course a totally independent attempt to analyze and criticize the influence of neoclassical economics on the regulations and standards of financial accounting. They make powerful arguments for considering the concept of income as more than a mere byproduct of the measurement of assets and liabilities.

I am deeply grateful to the contributors and appreciate all their comments, approving or critical, and accept them entirely. The only point that I do not want to leave undiscussed is Baker's claim that the combination of the ideas of evolution and progress led to the terrible tragedies of the twentieth century:

The nineteenth century ideas of evolutionary progress led almost directly to two world wars and multiple other lethal conflicts between socialism and capitalism during the twentieth century. The result was almost a century of worldwide warfare leading to the deaths of hundreds of millions of people. So while it is reasonable to explain the development of the revenue-expense approach as a form of ecological rationality, it is dangerous to assume that ecological rationality equates with social progress (Baker, 2017, p.6).

As Baker does not go into more detail, I can only guess that he is referring to Social Darwinism and the catastrophic impact it had, mostly as a part of the National Socialist program. If I understand Baker correctly, he has thus levelled a criticism of the concept of ecological rationality that deserves further comment.

Although it cannot be denied that there seems to be at least a parallel between Social Darwinism and ecological rationality, we would oversimplify dramatically if we held the latter concept in any way responsible for the crimes committed by National Socialists and others in the last 100 years. Most importantly, Social Darwinists consider the use of force and violence as a legitimate means in the 'natural' selection of societies (Eckert, 2002, p. 178). After all, National Socialists tried to interfere in the supposed battle of the human races in order to guarantee that the Aryans prevailed as the dominant race. What they called parasites and parasite races had to be actively eliminated from the Volkskörper (racial corpus) so that the Aryans could develop their virtues purely. The evolution alone did not bring about the wished-for results, and therefore racial laws, eugenics, and other political measures were considered necessary to create racial "progress." I must admit that I cannot see in how far the concept of ecological rationality - a concept that maintains the rationality of non-interference is to blame for having caused these effects "almost directly." In my view, it could be claimed with at least the same justification that Social Darwinism is a somewhat constructivist approach where progress is not expected from evolution, but from interference with evolution (Hayek, 1952).

But whether and in how far this is the case cannot be discussed in this short rejoinder. I simply want to point out that the relationship maintained by Baker between the concept of ecological rationality and the tragedies of the twentieth century cannot be upheld without major qualifications. The proposition that there is an ongoing trial-and-error process does not in any way have to lead to the conclusion that we must interfere with this process. In contrast, the concept of ecological rationality recommends non-interference and trust in the unhampered outcome. Whether this is always a good idea is another question, but it seems a stretch to claim that this principle caused the world wars and other tragedies of the twentieth century.

\section{References}

Baker, C. R. (2017). Commentary on Braun's "The ecological rationality of historical costs and conservatism". Accounting, Economics and Law: A Convivium. DOI: 10.1515/ael-2017-0049.

Basu, S. \& Waymire, G. B (2017). Historical cost and conservatism are joint adaptations that help identify opportunity cost. Accounting, Economics and Law: A Convivium. DOI: 10.1515/ael-2016-0070.

Biondi, Y. (2013). Accounting, economics, and law of the enterprise entity. A. C. Littleton and the German-American connection. In Y. Biondi \& S. Zambon (Eds.), Accounting and business economics. Insights from national traditions (pp. 363-386). New York and London: Routledge.

Braun, E (2017). The ecological rationality of historical costs and conservatism. Accounting, Economics and Law: A Convivium. DOI: 10.1515/ael2015-0013. 
Eckert, R. (2002). Gewalt/Politische Gewalt. In M. Greiffenhagen \& S. Greiffenhagen (Eds.), Handwörterbuch zur politischen Kultur der Bundesrepublik Deutschland (2nd ed., pp. 177-179). Wiesbaden: Westdeutscher Verlag.

Hayek, F. A. (1952). The counter-revolution of science. Studies on the abuse of reason. Glencoe, IL: Free Press.

Saito, S. \& Fukui, Y (2017). Whither the concept of income? Accounting, Economics and Law: A Convivium. DOI: 10.1515/ael-2016-0013.

Tang, V. W (2017). The role of accounting and the debate between historical cost and fair value. Accounting, Economics and Law: A Convivium. DOI: 10.1515/ael-2016-0066. 